\title{
New species of the Pseudancistrus barbatus group (Siluriformes, Loricariidae) with comments on its biogeography and dispersal routes
}

\author{
Gabriel de Souza da Costa e Silva ${ }^{1, \dagger}$, Fábio Fernandes Roxo ${ }^{1, \neq}$, \\ Ricardo Britzke ${ }^{1,8}$, Claudio Oliveira, ${ }^{1, \mid}$
}

I Laboratório de Biologia e Genética de Peixes, Departamento de Morfologia, IB-UNESP, Campus de Botucatu, 18618-000, Botucatu, SP, Brazil

† http://zoobank.org/BDE10BBD-857F-4EBD-81C6-1837CC05E60F

¥ http://zoobank.org/EEB03ED0-6A3A-4E11-BE30-4F5642DE5632

§ http://zoobank.org/17DBD9E4-E37A-450A-B258-2CE34A42159C

| http://zoobank.org/2E448127-8820-4F7C-9208-E2AB42ED3153

Corresponding author: Gabriel de Souza da Costa e Silva (gabriel_biota@hotmail.com)

\begin{tabular}{c|c|c|c|}
\hline Academic editor: Editor & Received 9 January $2014 \mid$ Accepted 15 April $2014 \mid$ Published 29 April 2014 \\
\hline http://zoobank.org/DA5BA33F-709C-404D-82E5-AB624A1D9F06 \\
\hline
\end{tabular}

Citation: Silva GSC, Roxo FF, Britzke R, Oliveira C (2014) New species of the Pseudancistrus barbatus group (Siluriformes, Loricariidae) with comments on its biogeography and dispersal routes. ZooKeys 406: 1-23. doi: 10.3897/ zookeys.406.7011

\begin{abstract}
A new species of Pseudancistrus is described from the Tapajós Basin, and assigned to the P. barbatus group by having hypertrophied odontodes along the snout and lacking evertible cheek plates. The new species is distinguished from other species in that group (P. barbatus, P. corantijniensis, P. depressus and $P$. nigrescens) by its pattern of spots, length and color of snout odontodes, greater head depth, cleithral width, anal-fin spine length, peduncle depth and internares width. Molecular phylogenetic results corroborate placement of the new species in the Pseudancistrus barbatus group which is otherwise distributed in the Xingu Basin and rivers draining the Guyana Shield into the Atlantic Ocean. Topology tests strongly reject alternative hypotheses supporting close relationships with Guyanancistrus, Lithoxancistrus or the species Pseudancistrus pectegenitor, P. sidereus and P. genisetiger. Additionally, we propose two hypotheses on the distribution of the new species in the rio Tapajós, a Brazilian Shield drainage. The first one proposes that ancestral stock of the P. barbatus group was widely distributed throughout rivers draining the Guyana and Brazilian
\end{abstract}

Copyright G. de Souza da Costa e Silva et al. This is an open access article distributed under the terms of the Creative Commons Attribution License (CC BY 4.0), which permits unrestricted use, distribution, and reproduction in any medium, provided the original author and source are credited. 
shields, and the species P. zawadzkii and Pseudancistrus sp. L17 are in the limit of the distribution for the group in Tapajós and Xingu rivers. The second hypothesis proposes that ancestral stock of the $P$. barbatus group was restricted to Guyana Shield rivers, and that headwater capture events permitted several dispersal routs through Guyana and Amazon rivers, permitted that the ancestral lineages of Pseudancistrus sp. L17 and $P$. zawadzkii reached the rivers of Amazon basin.

\section{Keywords}

Ancistrini, freshwater, molecular phylogeny, F-reticulon 4, Brazilian Shield

\section{Introduction}

Ancistrini is a highly diverse tribe of the subfamily Hypostominae, with 30 genera (Lujan and Armbruster 2011; Covain and Fisch-Muller 2012; Salcedo 2013) and 252 valid species (Eschmeyer and Fong 2013) widely distributed in the Neotropics from rivers in Panamá to the La Plata system in Argentina. Armbruster (2004a) provided morphological support for the monophyly of Ancistrini based on his extensive analysis of relationships within Loricariidae. Molecular data, however, suggested that Ancistrini is not monophyletic (Montoya-Burgos 1998; Covain and Fish-Muller 2012).

Species of the genus Pseudancistrus Bleeker, 1862 are distributed in the Orinoco, Amazon and Jaguaribe river systems, and rivers draining the Guyana Shield into the Atlantic Ocean. Armbruster (2004a) recognized Pseudancistrus as a monophyletic group and included Guyanancistrus Isbrücker, Seidel, Michels, Schraml \& Werner, 2001 and Lithoxancistrus Isbrücker, Nijssen \& Cala, 1988 in its synonymy. Based on molecular and morphological data, Chambrier and Montoya-Burgos (2008) defined a subgroup within Pseudancistrus called the Pseudancistrus barbatus group and composed of $P$. barbatus (Valenciennes, 1840), P. depressus (Günther, 1868), P. nigrescens Eigenmann, 1912, and P. corantijniensis De Chambrier \& Montoya-Burgos, 2008. That group was morphologically defined by having hypertrophied odontodes along the snout and lacking evertible cheek plates. Recently, Covain and Fisch-Muller (2012) suggested that Pseudancistrus guentheri (Regan, 1904) and P. kwinti Willink, Mol \& Chernoff, 2010 may be added to the P. barbatus group. Covain and Fisch-Muller (2012) also recognized Pseudancistrus as paraphyletic, and restricted the genus by the P. barbatus group. They revalidated the genera Guyanancistrus and Lithoxancistrus, and considered P. pectegenitor Lujan, Armbruster \& Sabaj Pérez, 2007, P. sidereus Armbruster, 2004b, and P. genisetiger Fowler, 1941 to represent two separate lineages unrelated to Pseudancistrus. Covain and Fisch-Muller (2012) suggested that these two lineages represent undescribed genera.

In this paper, we present a formal description of a new species of Pseudancistrus from the Tapajós river basin. Additionally, we provide a phylogenetic context for the new species based on analysis of sequence data of F-reticulon 4 nuclear gene, and a brief discussion of biogeographic scenarios that may explain the distribution of the new species in the rio Tapajós and northern Brazilian Shield. 


\section{Material and methods}

\section{Sampling and morphological analysis}

After capture, fish were anesthetized using $1 \%$ benzocaine in water, and either preserved in $95 \%$ ethanol for molecular studies or fixed in $10 \%$ formaldehyde for morphological studies. Vouchers and tissues were deposited in the collection of the Laboratório de Biologia e Genética de Peixes (LBP) and Museu de Zoologia da Universidade de Sáo Paulo (MZUSP), Brazil, Muséum d'histoire naturelle de la ville de Genève (MHNG), Switzerland, Academy of Natural Sciences of Philadelphia (ANSP) and Auburn University (AUM), U.S.A., and Smithsonian Tropical Research Institute (STRI), Panama. Measurements and counts were taken on left side of specimens. Measurements follow Armbruster (2003), and were taken point to point to the nearest $0.1 \mathrm{~mm}$ with digital calipers.

\section{DNA sequencing}

Total DNA was extracted from ethanol-preserved muscle, fin, and liver samples using the Wizard Genomic DNA Purification Kit (Promega, Madison, Wisconsin, U.S.A.). Partial sequences of F-reticulon 4 were amplified using polymerase chain reaction (PCR) with the following primers from Chiachio et al. (2008): Freticul4-D 5'-AGG CTA ACT CGC TYT SGG CTT TG-3', Freticul4-R 5'-GGC AVA GRG CRA ART CCA TCT C-3', Freticul4 D2 5'-CTT TGG TTC GGA ATG GAA AC-3', Freticul4 R2 5'-AAR TCC ATC TCA CGC AGG A-3', Freticul4 iR 5'-AGG CTC TGC AGT TTC TCT AG-3'.

Amplifications were performed in a total volume of $12.5 \mu$ l containing $1.25 \mu \mathrm{l}$ of 10X PCR buffer (20 mM Tris- $\mathrm{HCl}, \mathrm{pH} 8.0,40 \mathrm{mM} \mathrm{NaCl}, 2 \mathrm{mM}$ Sodium Phosphate, $0.1 \mathrm{mM}$ EDTA, $1 \mathrm{mM}$ DTT, stabilizers, $50 \%$ (v/v) glycerol), $0.375 \mu \mathrm{l} \mathrm{MgCl} 2$ (50nM), $0.25 \mu \mathrm{l}$ dNTPs $(2 \mathrm{nM}), 0.25 \mu \mathrm{l}$ (each $5 \mathrm{mM}$ primer), $0.05 \mu$ l Platinum ${ }^{\odot}$ Taq DNA Polymerase (Invitrogen), $1 \mu \mathrm{l}$ template DNA (50 ng), and $9.075 \mu \mathrm{lddH} 2 \mathrm{O}$. The nuclear markers were amplified in two PCR experiments; the first amplification using the primers Freticul4-D and Freticul4-R for $37-40$ cycles $\left(30 \mathrm{sec}\right.$ at $95^{\circ} \mathrm{C}, 30$ sec at $48^{\circ} \mathrm{C}$, and $135 \mathrm{sec}$ at $72^{\circ} \mathrm{C}$ ); and the second amplification using the primers Freticul 4 D2, Freticul4 R2, and Freticul 4 iR for $37-40$ cycles $\left(30 \mathrm{sec}\right.$ at $95^{\circ} \mathrm{C}, 30 \mathrm{sec}$ at $53-54^{\circ} \mathrm{C}$, and $135 \mathrm{sec}$ at $72^{\circ} \mathrm{C}$ ).

The products were then identified on a $1 \%$ agarose gel. The PCR products were purified using ExoSap-IT ${ }^{\oplus}$ (USB, Affymetrix Corporation, Cleveland, Ohio) following the manufacturer's instructions. The purified PCR products were used to make a sequencing PCR using the BigDyeTM Terminator v 3.1 Cycle Sequencing Ready Reaction Kit (Applied Biosystems- Life Technologies do Brasil Ltda, Vila Guarani, SP, Brazil). Subsequently, the amplified DNA was purified again and loaded onto a 3130-Genetic Analyzer automatic sequencer (Applied Biosystems), in the Instituto de Biociências, Universidade Estadual Paulista, Botucatu, São Paulo. Contigs were as- 
sembled and edited in BioEdit 7.0.9.0 (Hall 1999). Where uncertainty of nucleotide identity was detected, IUPAC ambiguity codes were applied. All sequences obtained in this study were deposited in GenBank (Table 3).

\section{Sequence alignment and phylogenetic analyses}

The DNA sequences were aligned using ClustalW program implemented in DAMBE 5.2.31 (Xia and Xie 2001) and edited in BioEdit 7.0.1 (Hall 1999), using default parameters. The alignments were inspected by eye for any obvious misalignments that were then corrected. Alignment errors only were changed where indels of $1 \mathrm{bp}$ were added to introns of the reticulon gene. The sequence of F-reticulon 4 of the new species was sequenced twice, and a preliminary phylogenetic analysis was performed to control potential sequencing errors involving pseudogenes, paralogous copies or laboratory crosscontamination or mistakes during manipulations of samples. Nucleotide variation was examined using MEGA 5.0 (Tamura et al. 2007). To evaluate the occurrence of substitution saturation, we estimated the index of substitution saturation (Iss) in DAMBE 5.2.31 (Xia and Xie 2001), as described by Xia et al. (2003) and Xia and Lemey (2009).

Maximum-Likelihood (ML) analyses were performed using RAxML Web-Servers (Randomized Accelerated Maximum Likelihood, Stamatakis et al. 2008) which implements a faster algorithm of heuristic search with bootstrap pseudoreplicates (RBS). Bootstrap resampling (Felsenstein 1985) was applied to assess support for individual nodes using 1,000 replicates. Random starting trees were used for each independent ML tree search and all other parameters were set on default values. The ML analysis was conducted under a Generalized Time Reversible (GTR) model, with Gamma distribution $(\mathrm{G})$ and Invariable Sites according to Modeltest 3.7 results (Posada and Crandall 1998). Gaps were treated as missing data.

Alternative tree topologies were evaluated in the program Treefinder (Jobb et al. 2004) using the Shimodaira and Hasegawa (SH) test (Shimodaira and Hasegawa 1999), the Approximately Unbiased (AU) test (Shimodaira 2002), and the Expected Likelihood Weights (ELW) method (Strimmer and Rambaut 2002). All tests were conducted under ML with a GTR model and Gamma distribution.

\section{Results}

\section{Pseudancistrus zawadzkii sp. n.} http://zoobank.org/F244A7A4-253A-49B8-B027-16B640FDBCCF http://species-id.net/wiki/Pseudancistrus_zawadzkii Figure 1, Table 1

Holotype. MZUSP 115056, male, $116.4 \mathrm{~mm}$ SL. Brazil: Pará State: municipality of Itaituba: rio Tapajós (Amazon basin), 04³3'09.7"S, 56²17'59.6"W, 11 June 2012, R. Britzke and CEPTA's team. 


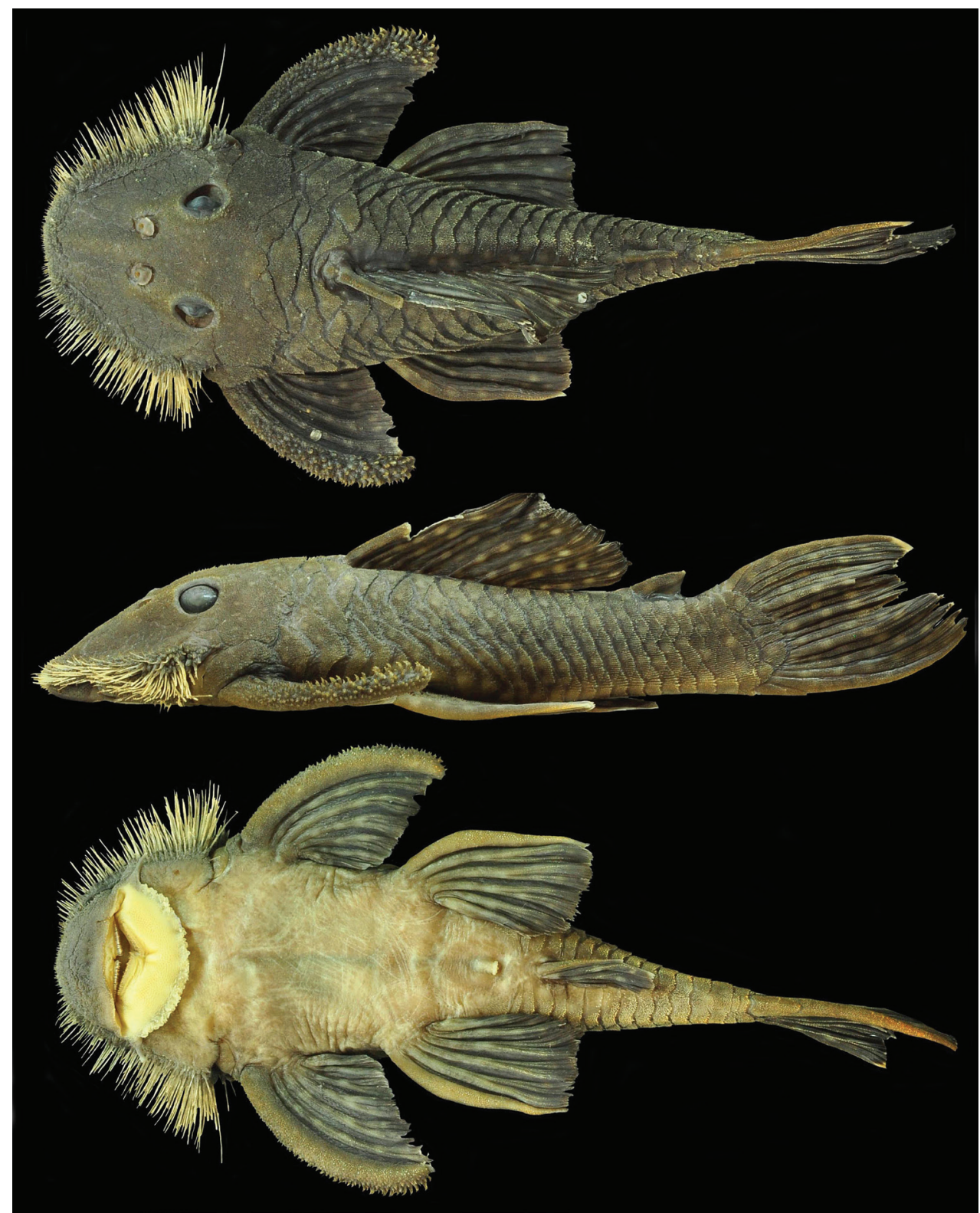

Figure I. Pseudancistrus zawadzkii, MZUSP 115056, holotype, male, 116.4 mm SL; Pará State, Tapajós river basin, Brazil.

Paratypes. Brazil: Pará State: municipality of Itaituba: LBP 15045 (2 females, 97.9-128.7 mm SL), LBP 17724 (1 female, $87.5 \mathrm{~mm} \mathrm{SL}$ ), collected with holotype; LBP 16195 (1 male, $116.4 \mathrm{~mm} \mathrm{SL}$ ), rio Tracuá (trib. rio Tapajós), 04²28'11.2"S, $56^{\circ} 17^{\prime} 01.1$ "W.

Diagnosis. Pseudancistrus zawadzkii is distinguished from all congeners, except species of the $P$. barbatus group, by presence of hypertrophied odontodes along the snout 


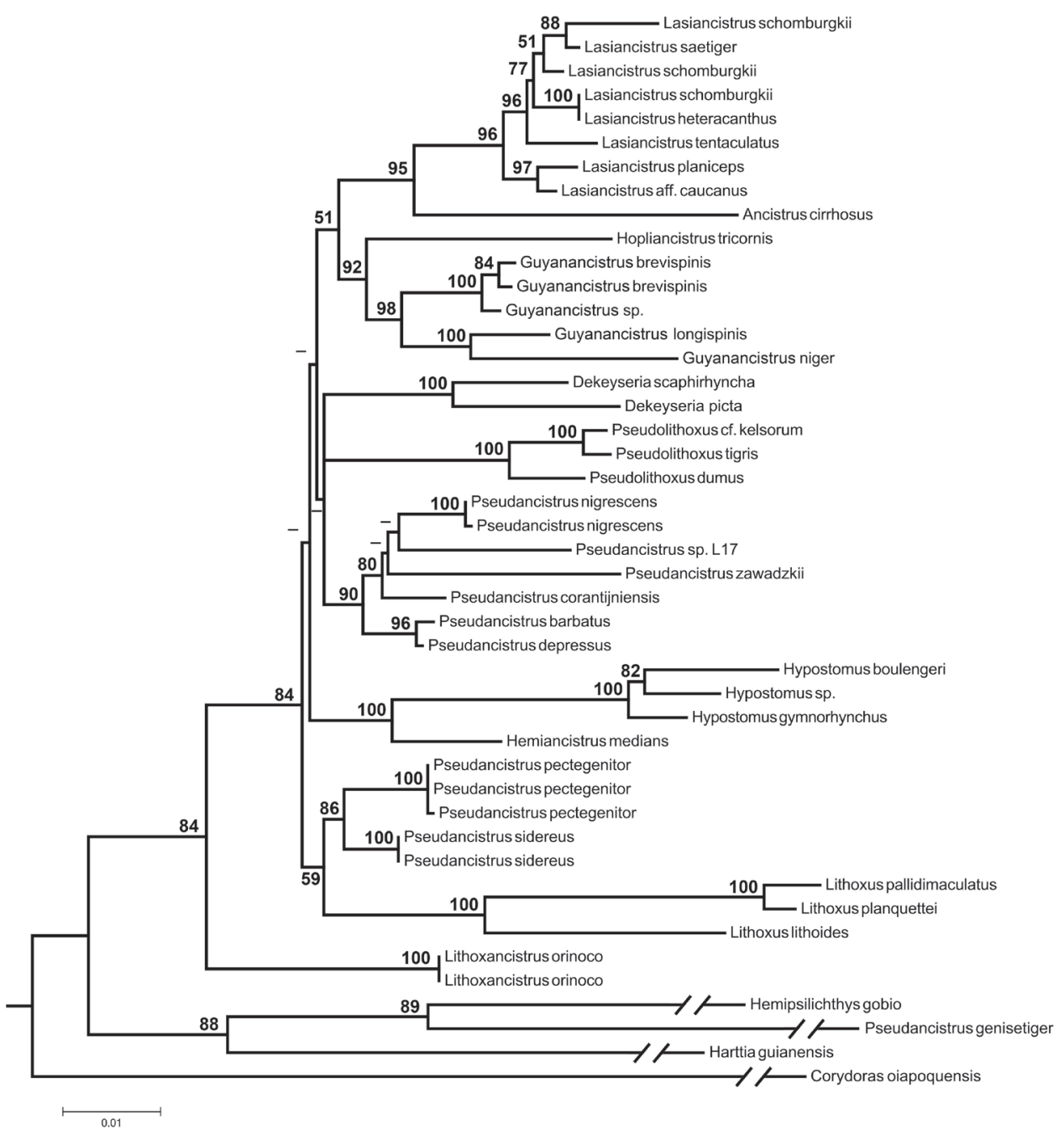

Figure 2. Maximum-likelihood tree based on nuclear gene sequence F-reticulon $4(-\operatorname{lnL}=11470.59)$. Numbers next to nodes are bootstrap values based on 1,000 pseudoreplicates. Values below 50\% are not shown.

margin and the lack of evertible cheek plates. It further differs from two members of that group, $P$. barbatus and $P$. depressus, by having whitish spots that abruptly increase in size between the head (diameter 1.1-1.3 mm) and body (diameter 2.6-3.0 mm) (vs. whitish spots very small on whole body less than $1 \mathrm{~mm}$ ), and snout odontodes yellowish (vs. snout odontodes reddish-brown). The new species differs from the other two members of the $P$. barbatus group, $P$. corantijniensis and $P$. nigrescens, by having odontodes along margin of snout increasing gradually in length from posterior of snout tip to cheek (vs. length of snout odontodes more uniform, smaller on tip of snout) and by having odontodes relatively longer on the most posterior portion of the nonevertible check plates (Fig. 1) (vs. odontodes shorter) (see fig. 3 in Chambrier and Montoya- 
Table I. Morphometric data for Pseudancistrus zawadzkii.

\begin{tabular}{|c|c|c|c|c|}
\hline & \multicolumn{4}{|c|}{ Pseudancistrus zawadzkii $\mathrm{n}=5$} \\
\hline & Holotype & Range & Mean & SD \\
\hline Standard length (SL) & 116.4 & $128.7-87.5$ & 109.5 & \\
\hline \multicolumn{5}{|l|}{ Percents of SL } \\
\hline Predorsal length & 43.3 & $43.1-46.1$ & 44.5 & 1.3 \\
\hline Head length & 36.6 & $32.9-37.8$ & 36.3 & 1.9 \\
\hline Head-dorsal length & 6.7 & $6.7-9.2$ & 8.1 & 1.2 \\
\hline Cleithral width & 35.2 & $35.2-38.0$ & 36.7 & 1.2 \\
\hline Head pectoral length & 30.5 & $29.6-32.2$ & 30.9 & 0.9 \\
\hline Thorax length & 23.5 & $21.2-23.5$ & 22.5 & 1.1 \\
\hline Pectoral-spine length & 31.5 & $31.3-33.2$ & 31.9 & 0.7 \\
\hline Abdominal length & 24.2 & $22.6-26.1$ & 24.3 & 1.3 \\
\hline Pelvic-spine length & 28.4 & $25.6-28.4$ & 27.2 & 1.2 \\
\hline Post-anal length & 31.2 & $29.6-31.2$ & 30.5 & 0.7 \\
\hline Anal-fin spine length & 12.5 & $11.9-13.8$ & 12.6 & 0.7 \\
\hline Dorsal pectoral depth & 27.3 & $26.6-30.7$ & 28.6 & 1.7 \\
\hline Dorsal spine length & 24.7 & $24.7-29.9$ & 27.5 & 2.3 \\
\hline Dorsal pelvic depth & 22.9 & $22.1-26.4$ & 24.1 & 1.7 \\
\hline Dorsal-fin base length & 31.2 & $29.1-31.2$ & 30.0 & 1.0 \\
\hline Dorsal-adipose distance & 11.2 & $10.5-13.7$ & 11.6 & 1.2 \\
\hline Adipose-spine length & 7.8 & $6.79-8.78$ & 7.8 & 0.7 \\
\hline Dorsal adipose caudal distance & 11.7 & $11.7-15.6$ & 13.7 & 1.7 \\
\hline Caudal peduncle depth & 12.5 & $12.5-14.2$ & 13.3 & 0.6 \\
\hline Ventral adipose caudal distance & 22.9 & $22.9-25.3$ & 23.9 & 1.0 \\
\hline Adipose anal distance & 21.3 & $18.5-21.3$ & 19.8 & 1.0 \\
\hline Dorsal-anal distance & 16.0 & $15.8-17.8$ & 16.8 & 0.8 \\
\hline Pelvic-dorsal distance & 29.5 & $22.0-29.5$ & 22.5 & 2.7 \\
\hline \multicolumn{5}{|l|}{ Percents of head length (HL) } \\
\hline Head-eye length & 29.4 & $28.1-30.1$ & 29.1 & 0.8 \\
\hline Orbital diameter & 14.6 & $14.5-18.8$ & 15.8 & 1.7 \\
\hline Snout length & 63.2 & $63.2-70.5$ & 66.8 & 3.1 \\
\hline Internares width & 14.4 & $12.7-16.6$ & 14.4 & 1.4 \\
\hline Minimal interorbital distance & 28.8 & $28.8-35.7$ & 32.2 & 2.5 \\
\hline Mouth length & 53.8 & $52.0-60.6$ & 55.7 & 3.5 \\
\hline Barbel length & 14.0 & $7.6-14.0$ & 10.6 & 2.6 \\
\hline Dentary tooth cup length & 17.6 & $17.0-19.6$ & 18.5 & 1.1 \\
\hline Premaxillary tooth cup length & 17.8 & $17.2-19.2$ & 18.2 & 0.7 \\
\hline Head depth & 68.9 & $67.0-72.7$ & 68.8 & 2.3 \\
\hline
\end{tabular}

Burgos 2008 for comparison of both characters). Additionally, P. zawadzkii differs from $P$. nigrescens by having rounded spots that do not cover more than one plate along the body (vs. whitish spots that become hazier along the body and can cover more than one plate, see P. nigrescens in fig. 3 in Chambrier and Montoya-Burgos (2008). Moreover, 
P. zawadzkii is distinguished by having a greater head depth, $67.0-72.7 \%$ of HL (vs. $38.3-44.9 \%$ of HL in P. barbatus; $40.6-53.0 \%$ of HL in P. corantijniensis, data based on original description; and $52.5-56.6 \%$ of $\mathrm{HL}$ in $P$. nigrescens); greater cleithral width, $35.2-38.0 \%$ of SL (vs. $31.1-32.7 \%$ of SL in $P$. nigrescens and $29.7-33.4 \%$ of SL in $P$. barbatus); shorter distance between posteromedial margin of supraoccipital and origin of dorsal-fin, $6.7-9.2 \%$ of SL (vs. $10.4-11.6 \%$ of SL in P. nigrescens); greater anal-fin spine length, $11.9-13.8 \%$ of SL (vs. 7.3-10.4 of SL in P. barbatus); greater peduncle depth, $12.5-14.2 \%$ of SL (vs. 9.3-10.4 of SL in P. barbatus); and wider internares distance, $12.7-16.6 \%$ of HL (vs. 9.9-11.8\% of HL in P. barbatus). Pseudancistrus zawadzkii differs from $P$. kwinti and $P$. guentheri, two probable members of $P$. barbatus group by having whitish spots of the body (vs. body mottled or with bars, in $P$. kwinti and body plates dark at the base and pale along the edges, in P. guentheri).

Description. Morphometric data presented in Table 1. In lateral view, dorsal profile convex from snout tip to dorsal-fin origin; straight, gradually descending from dorsal-fin origin to posterior insertion of adipose fin; straight, steeply ascending to insertion of caudal fin; ventral profile flat from snout tip to anal-fin origin; shallowly concave from anal-fin insertion to lower caudal-fin spine; greatest body depth at dorsal-fin origin. In dorsal view, greatest body width across cleithral region; snout broadly elliptical; body progressively narrowed from opercular region to caudal fin. Cross-section of body between pectoral and pelvic fins rounded dorsally and flattened ventrally; cross-section of caudal peduncle ellipsoid.

Body almost entirely covered by plates; ventral portions of head and abdomen and dorsal-fin base naked. Five lateral rows of dermal plates, dorsal plates 21-24, lateral mid-dorsal plates 19-21, lateral median plates 22-24, lateral mid-ventral plates 21-24, lateral ventral plates 18-20. Three predorsal plates; eight plates below dorsalfin base; four plates between dorsal fin and adipose fin; five rows of plates on caudal peduncle. Dorsal spinelet present.

Body plates and cleithrum have minute odontodes. Odontodes slightly hypertrophied on pectoral-fin spines, becoming gradually larger towards tips. Numerous yellowish hypertrophied odontodes along lateral margins of head including snout; odontodes small on tip of snout, increasing gradually in length from anterolateral margin of snout to cheeks; longest odontodes on posterior most portion of non-evertible cheek plates. Eyes small (orbital diameter $14.5-18.8 \%$ of HL), dorsolaterally positioned. Oral disk transversely ellipsoid. Lower lip not reaching transverse line between gill openings. Lower lip covered with numerous small papillae. Maxillary barbel developed. Mouth relatively large. Premaxillary teeth 40-61 per ramus; dentary teeth 28-69 per ramus. Teeth bifid, medial cusp large and rounded, lateral cusp minute and pointed. Wide jaws, dentary bones forming an oblique angle, premaxillary bones almost co-linear.

Dorsal fin II,7, origin approximately at midpoint between pectoral- and pelvic-fin origins, last dorsal-fin ray reaching adipose fin when depressed. Pectoral fin I,6, spine tip curved inward, covered with enlarged odontodes distally; depressed tip reaching one-third length of pelvic-fin spine. Pelvic fin I,5, spine tip curved inward, almost reaching anal-fin origin when depressed. Anal fin I,5, spine tip straight, reaching sev- 


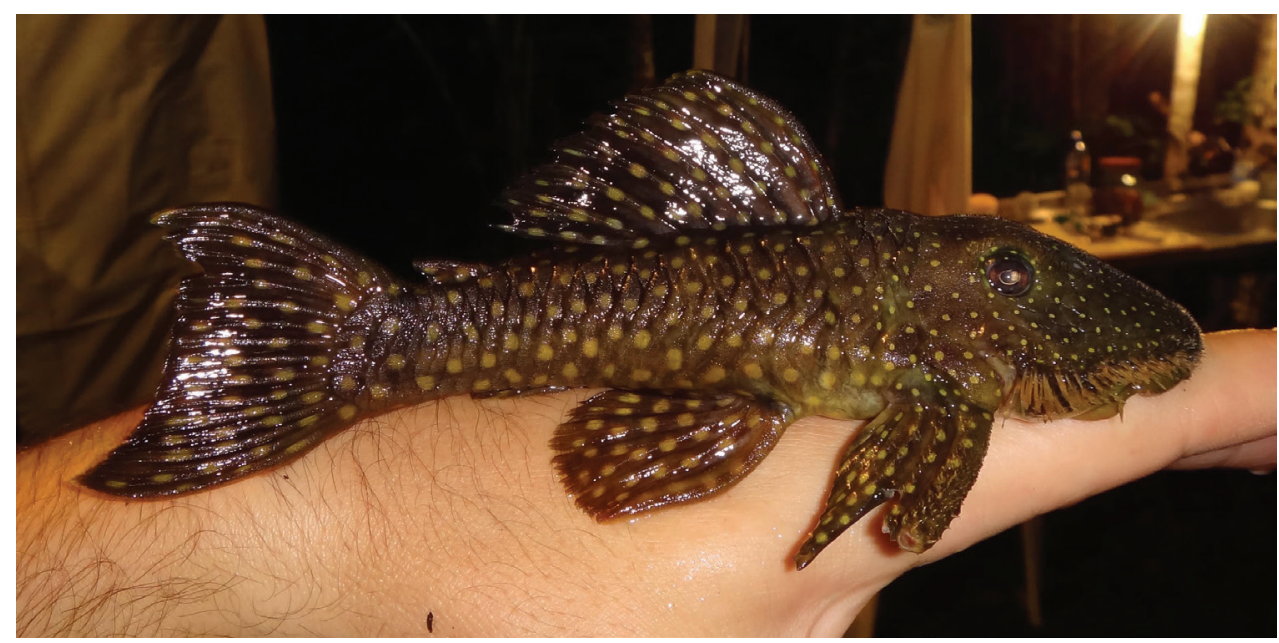

Figure 3. Pseudancistrus zawadzkii, live specimen, LBP 15045, paratype, female, 128.7 mm SL, Tapajós river, Pará State, Brazil.

enth plate posterior to its origin. Caudal fin I,7-I,7, distal margin concave, inferior lobe longer than superior. Adipose fin with lightly curved spine, preceded by single median preadipose plate.

Color in life. Ground color dark greenish-brown on dorsum and sides of body, becoming dark brown posteriorly, and lighter brown ventrally. Anterior portion of head to posterior margin of orbits with many small, crowded, yellow spots; spots becoming abruptly larger on posterior portion of head, continuing on body, becoming slightly and gradually larger towards caudal peduncle. Dorsal plate series usually with two large spots per plate. Mid-dorsal plates usually with one large spot per plate. Lateral median plates with one large spot per plate. Mid-ventral plates and ventral plates with one large spot per plate. Dorsal-fin spine, rays and membranes with large round large spots. Adipose-fin with two large spots on spine and membrane. Pectoral, pelvic, anal and caudal fin with numerous and similarly sized yellow spots. Hypertrophied odontodes along head margin yellowish (Fig. 3).

Color in alcohol. Similar to pattern described for living individuals, but with ground color dark brown, and spots pale tan (Fig. 1).

Sexual dimorphism. Males possess a papilla posterior to urogenital opening, an attribute absent in females. Both sexes in P. zawadzkii exhibit highly hypertrophied odontodes along snout margin, similar to others species of Pseudancistrus (Armbruster 2004b). In some loricariid species of genus Pareiorhaphis those hypertrophied odontodes may be sexually dimorphic (Pereira et al. 2007), an attribute not observed in the new species $P$. zawadzkii.

Etymology. Specific name is in honor of Cláudio Henrique Zawadzki, professor at Universidade Estadual de Maringá (UEM), Maringá, Paraná State, Brazil, in recognition of his dedication and remarkable contributions to the study of the family Loricariidae. 


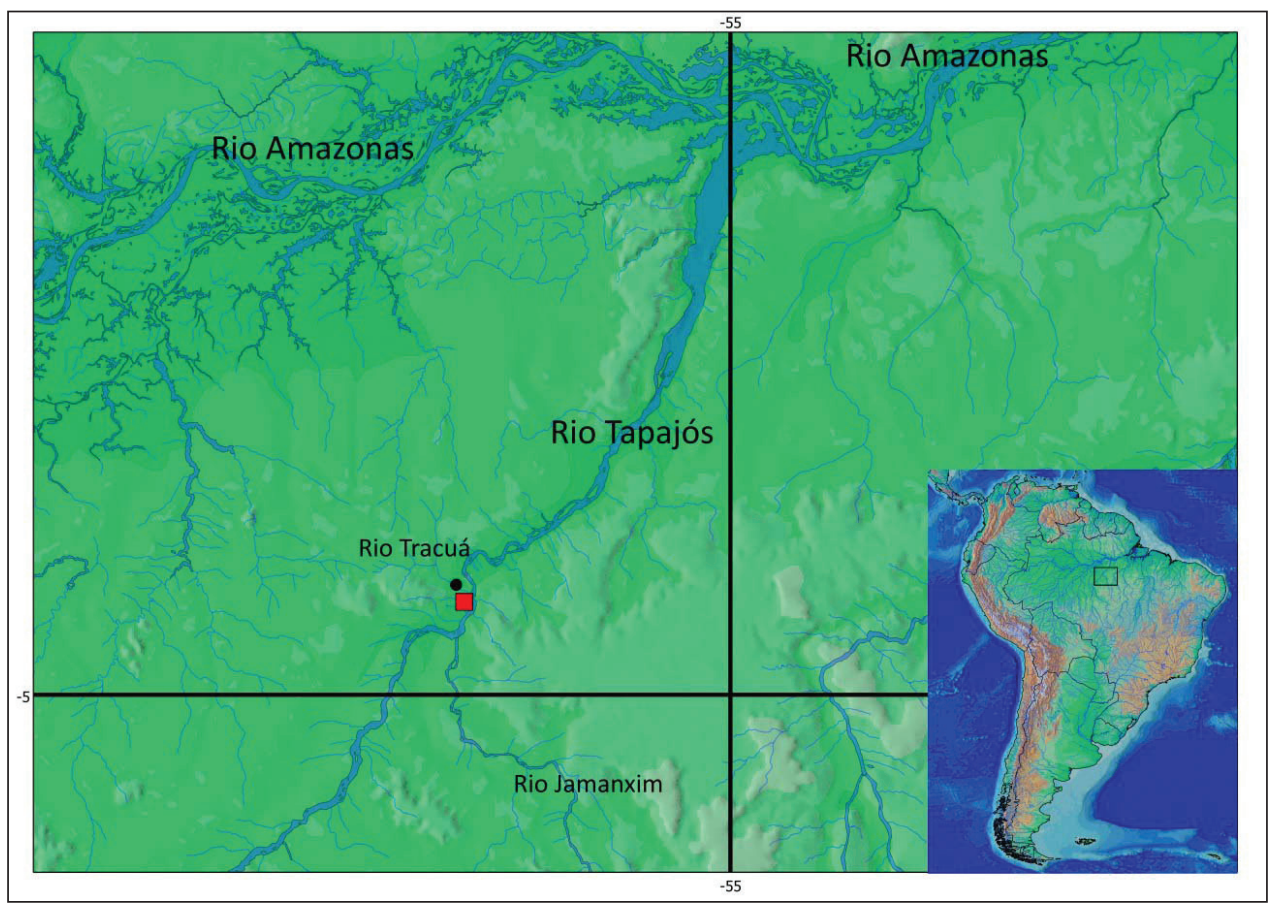

Figure 4. Map showing the type locality (red square) of Pseudancistrus zawadzkii at rio Tapajós, $04^{\circ} 33^{\prime} 09.7^{\prime \prime}$ S, 56 $17^{\prime} 59.6^{\prime \prime} \mathrm{W}$, and paratype locality (black circle) at rio Tracuá, Tapajós river basin, $04^{\circ} 28^{\prime} 11.2^{\prime \prime} \mathrm{S}, 56^{\circ} 17^{\prime} 01.1^{\prime \prime W}$.

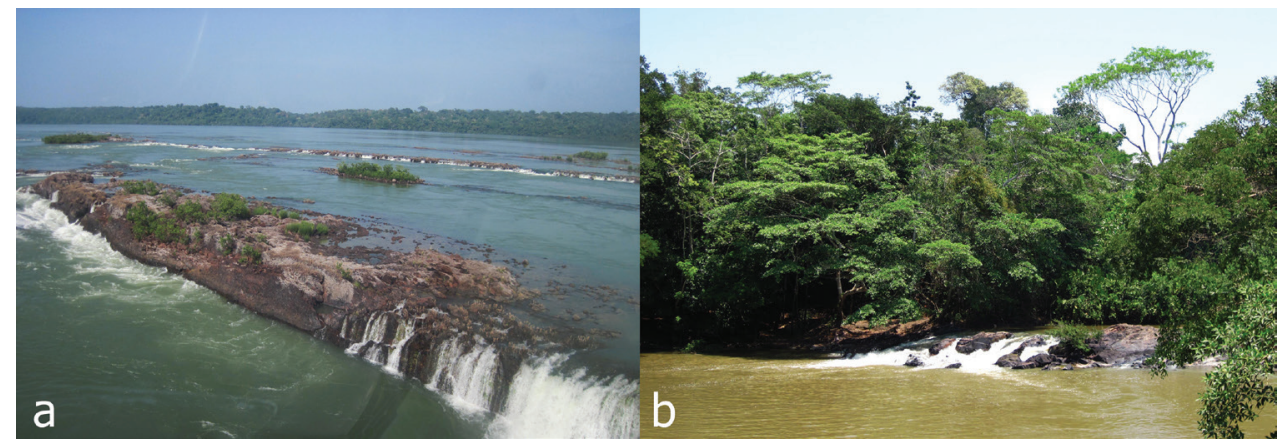

Figure 5. a Habitat at type locality of Pseudancistrus zawadzkii: rio Tapajós, municipality of Itaituba, Pará State, Brazil b habitat at paratype locality: rio Tracuá, Tapajós river basin, municipality of Itaituba, Pará State, Brazil.

Distribution. Pseudancistrus zawadzkii is known from rio Tapajós $\left(04^{\circ} 33^{\prime} 10^{\prime \prime} S\right.$, $\left.56^{\circ} 18^{\prime \prime} \mathrm{W}\right)$ and rio Tracuá $\left(04^{\circ} 28^{\prime} 11^{\prime \prime} \mathrm{S}, 56^{\circ} 17^{\prime} 01 \mathrm{\prime W}\right)$, municipality of Itaituba, all from rio Tapajós basin, Pará State, Brazil. (see Fig. 4 for distribution map of type species localities). 
Ecological notes. The rio Tapajós, and rio Tracuá where $P$. zawadzkii occurs are clear water rivers, varying from medium to large size, with rocky outcrops forming small waterfalls and substrates of rocks and sand (Fig. 5).

\section{Phylogenetic analysis}

Partial sequences of the nuclear gene F-reticulon 4 (RTN4) were obtained in this study and from GenBank for 44 specimens representing 35 Loricariidae species and the new species P. zawadzkii (Table 3). We included samples of the four lineages of Pseudancistrus proposed by Covain and Fisch-Muller (2012) to test whether P. zawadzkii is part of the P. barbatus group. Corydoras oiapoquensis Nijssen, 1972 (Callichthyidae) was used to root the phylogeny. Additionally, samples of Delturinae (Hemipsilichthys gobio Lutken, 1874) and Loricariinae (Harttia guianensis Rapp Py-Daniel \& Oliveira, 2001) were included in the analysis as additional outgroups. The combined sequence data resulted in a matrix with 2,318 base pairs (bp), out of which 1,079 were conserved and 896 were variable. The estimated index of substitution saturation (Iss) performed in DAMBE 5.2.31 (Xia and Xie 2001) showed that the data was not saturated (i.e. Iss.c value greater than Iss).

Evolutionary relationships among species of Pseudancistrus sensu lato and other members of Otothyrini are similar between our ML phylogenetic tree (- $\operatorname{lnL}$ $=11470.59)$ and the one proposed by Covain and Fisch-Muller (2012). In our analysis, the genus Pseudancistrus is paraphyletic with species assigned to three different lineages. The first lineage is monotypic, composed of $P$. genisetiger, sister to H. gobio, an outgroup taxon. Covain and Fisch-Muller (2012) suggested that $P$. genisetiger represents an undescribed genus within Delturinae. The second lineage of Pseudancistrus (P. sidereus $+P$. pectegenitor) is sister to a species of Lithoxus Eigenmann, 1910; Covain and Fisch-Muller (2012) suggested that the two species represent an undescribed genus or may be included in Lithoxus. The third lineage is composed of members of the $P$. barbatus group ( $P$. depressus, $P$. barbatus, $P$. corantijniensis, $P$. nigrescens, the new species $P$. zawadzkii and an undescribed species from the rio Xingu known as L17 among hobbyists). The P. barbatus group forms a polytomy with almost all species analyzed in the ingroup (Fig. 3), and was recognized by Covain and Fisch-Muller (2012) as true Pseudancistrus since this group includes the type species $P$. barbatus. Additionally, Covain and FischMuller (2012) revalidated two genera for several species previously assigned to Pseudancistrus, - Lithoxancistrus (for Pseudancistrus orinoco (Isbrücker, Nijssen \& Cala, 1988)) and Guyanancistrus (for Pseudancistrus sp., P. brevispinis (Heitmans, Nijssen \& Isbrücker, 1983), P. longispinis (Heitmans, Nijssen \& Isbrücker, 1983) and $P$. niger (Norman 1926)). Our analysis also supports the recognition and composition of those two genera. 


\section{Discussion}

\section{Taxonomy and phylogenetic comparison}

The new species $P$. zawadzkii possesses hypertrophied odontodes along the snout margin and lacks evertible cheek plates. Armbruster (2004b) identified that among Ancistrini, only Pseudolithoxus, Lithoxancistrus, and some members of Guyanancistrus and Pseudancistrus share the presence of hypertrophied odontodes along the snout in both sexes. Armbruster (2004b) also suggested that the species of Pseudancistrus that present this characteristic are derived; those species correspond to the P. barbatus group proposed by Chambrier and Montoya-Burgos (2008). Therefore, the new species described herein is a typical member of this group sensu Covain and Fisch-Muller (2012). Our phylogenetic analysis (Fig. 3) supports that hypothesis, and places the new species in a polytomy with $P$. corantijniensis, Pseudancistrus sp. L17 (undescribed species) and $P$. nigrescens, within the P. barbatus group. Our likelihood-based tests strongly rejected alternative topologies placing the new species in Lithoxancistrus, Guyanancistrus or with other species of Pseudancistrus apart from the P. barbatus group (see Table 2).

Pseudancistrus zawadzkii, P. corantijniensis, and P. nigrescens share the presence of whitish colored snout odontodes and a dark colored body covered with white spots. The new species can be easily distinguished from $P$. corantijniensis and $P$. nigrescens by having large hypertrophied odontodes on the posteriormost portion of the nonevertible check plates, and marginal odontodes that increase gradually in length from tip of snout to cheeks. Pseudancistrus barbatus and P. depressus share reddish-brown snout odontodes, a probable synapomorphy, and are the sister group to $P$. zawadzkii, P. corantijniensis and P. nigrescens. Covain and Fisch-Muller (2012) suggested that $P$. guentheri and P. kwinti may be added to the P. barbatus group. However, those two species have a different body coloration pattern (Chambrier and Montoya-Burgos 2008; see fig. 3); in P. kwinti the body is either mottled or with bars, while in P. guentheri the body plates are dark at the base and pale along the edges (Willink et al. 2010).

\section{Biogeography and dispersal routes}

Named species of the P. barbatus group are distributed in rivers draining to Guyana Shield into the Atlantic Ocean, and the new species described herein is from Tapajós river draining of Brazilian Shield into the Amazon. In our phylogeny, species from the eastern Guyana Shield ( $P$. barbatus and $P$. depressus) form a clade sister to a group composed of species from the western Guyana Shield (P. corantijniensis and P. nigrescens) and Amazon basin (P. zawadzkii and Pseudancistrus sp. L17) (Fig. 6). Therefore, based on this interpretation and our results of phylogenetic analysis, we suggested two hypotheses that could generate the distribution pattern of $P$. barbatus group extant-species. The first hypothesis is that the ancestral stock of the P. barbatus group was widely distributed through all Guyana Shield rivers and Amazon Brazilian Shield rivers, and 
Table 2. Likelihood-based tests for alternative topologies. SH and AU are probability values obtained from the Shimodaira-Hasegawa and the Approximately Unbiased tests (Shimodaira 2002). Asterisks denote significant values $(\mathrm{P}<0.05$ for $\mathrm{SH}$ and $\mathrm{P}<0.01$ for $\mathrm{AU}$ and $\mathrm{ELW})$ that imply the topology is rejected.

\begin{tabular}{|c|c|c|c|c|c|c|}
\hline Test & Topology & $-\operatorname{Ln} L$ & $\Delta-\operatorname{Ln} L$ & ELW & SH & AU \\
\hline & ML & 11910.81 & & & & \\
\hline 1 & $\begin{array}{c}\text { P. zawadzkii sister group to } P \text {. pectegenitor }+ \\
\text { P. sidereus }{ }^{\text {a }}\end{array}$ & 11952.41 & 41.60 & $<0.001^{*}$ & $0.021^{*}$ & $<0.001^{*}$ \\
\hline 2 & $\begin{array}{l}\text { P. zawadzkii sister group to } \\
\text { Guyanancistrus members }{ }^{\text {a }}\end{array}$ & 11962.24 & 51.43 & $<0.001^{*}$ & $0.011^{*}$ & $<0.001^{*}$ \\
\hline 3 & $\begin{array}{l}\text { P. zawadzkii sister group to } \\
\text { Lithoxancistrus members }\end{array}$ & 11966.25 & 55.44 & $<0.001^{*}$ & $<0.001^{*}$ & $<0.001^{*}$ \\
\hline 4 & P. zawadzkii sister group to $P$. genisetiger ${ }^{a}$ & 12033.30 & 122.49 & $<0.001^{*}$ & $<0.001^{*}$ & $<0.001^{*}$ \\
\hline
\end{tabular}

a The alternative topology was defined as the ML tree forcing the desired relationship.

the species P. zawadzkii and Pseudancistrus sp. L17 are in the limit of the distribution for the group in Tapajós and Xingu rivers, respectively. Gaston (1998) and Hubbell (2001) suggested that when allopatric divergence is the dominant mode of speciation, many daughter species are expected to arise from geographically widespread ancestral species. This is a reasonable interpretation given that named species of the group are widespread in rivers draining Guyana Shield into the Atlantic Ocean; the new species P. zawadzkii are from Tapajós river drainage of Amazon Brazilian Shield; the possible new and undescribed species Pseudancistrus sp. L17 are from Xingu river which also belongs to drainages of Amazon Brazilian Shield and others possible new and undescribed species of $P$. barbatus group may be present in drainages of Guyana Shield into Amazon (Pseudancistrus sp. L220 from rio Paru; Pseudancistrus sp. L251 from rio Cuminá (rio Erepecuru); Pseudancistrus sp. L383 from rio Trombetas; Pseudancistrus sp. L440 from rio Jatapu (Seidel 2008)). However, phylogenetic and taxonomic studies are necessary to confirm that the latter undescribed species belong to $P$. barbatus group.

The second hypothesis suggests that the ancestral stock of $P$. barbatus group should have been distributed through Guyana Shield rivers and there existed several dispersal routes through Guyana and Amazon rivers, permitting that the ancestral lineages of Pseudancistrus sp. L17 and P. zawadzkii reached the rivers of Amazon basin (see Fig. 7 for dispersal routes). Therefore, examples of connections and areas of movement among Guyana drainages and the north tributaries of Amazon basin was reported by several authors: (1) the Rupununi portal, an example of seasonal connection among Takutu and Rupununi rivers (Armbruster and Werneke 2005; Lujan and Armbruster 2011; De Souza et al. 2012); (2) the corridor among Sipalawini (Corantijn river basin) and the Paru do Oeste (Amazon basin), also connected only in the rainy season (Nijssen 1972; Lujan and Armbruster 2011); (3) the Cassiquiare Canal, a large and permanently navigable corridor between the upper Orinoco and the upper Rio Negro (Amazon) (Chernoff et al. 1991; Buckup 1993; Schaefer and Provenzano 1993; Lovejoy and Araújo 2000; Turner et al. 2004; Moyer et al. 2005; Willis et al. 2007; Winemiller et al. 2008; Winemiller and Willis 2011); (4) Proto-Berbice, a river system which had its headwaters in an ancient 


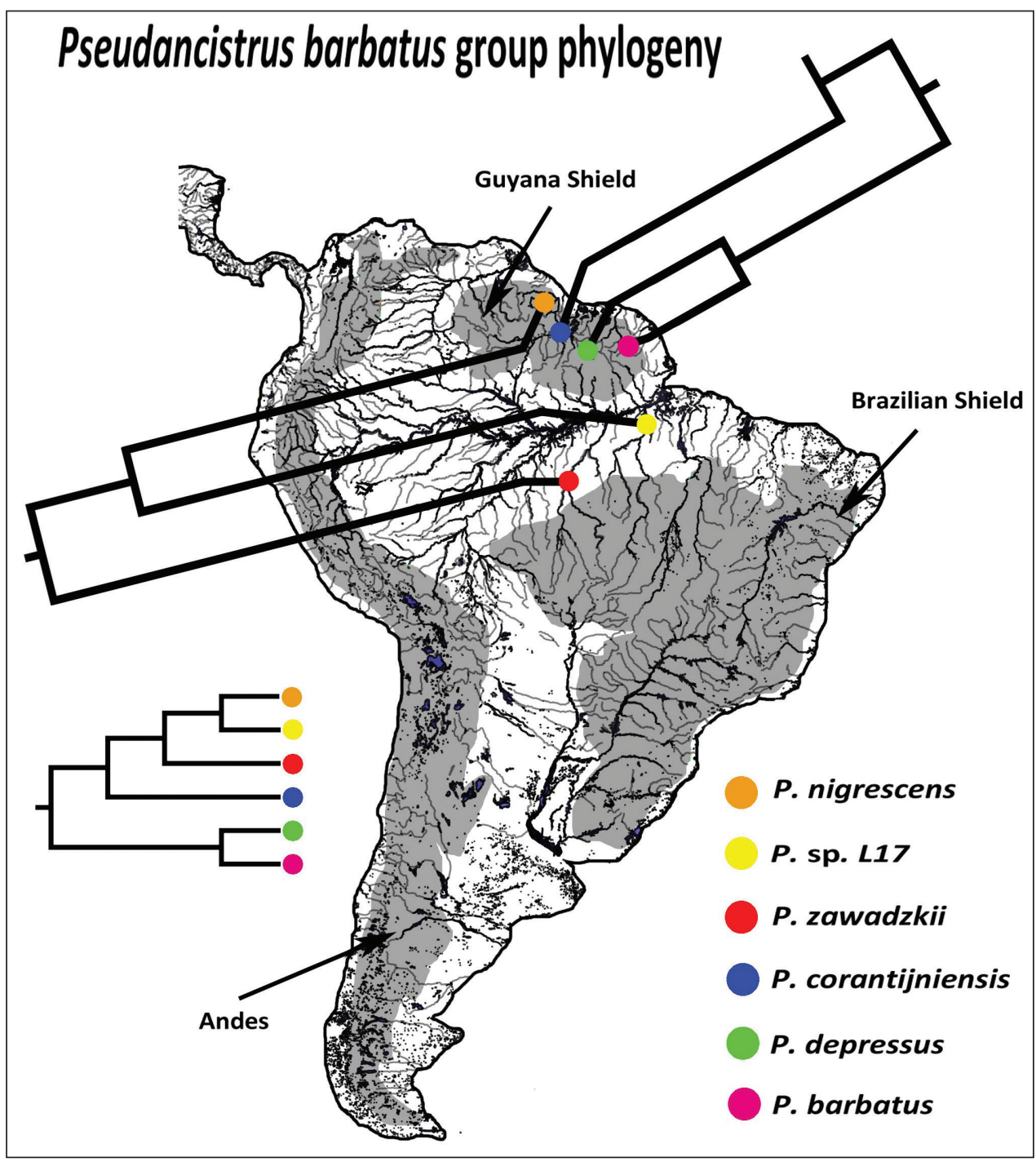

Figure 6. Distribution and phylogenetic relationships of species of the Pseudancistrus barbatus group based on F-reticulon 4 gene. Based in our first hypothesis of extand-species distribution of this group the ancestral was widespread through all Guyana Shield rivers and Amazon Brazilian Shield rivers, the species Pseudancistrus zawadzkii and Pseudancistrus sp. L17 are in the limited distribution of this group in Tapajós and Xingu rivers, drainages of Brazilian Shield into Amazon.

mountain range draining northward to Guyana system (Rupununi and Essequibo rivers) and suffered a major sedimentation, erosion and/or corrosion of the highlands and at the end of the Pliocene had its head waters captured by the Amazon system; (5) the Atlantic coastal corridors resulted in a coastal marine corridor with reduced salinity due to the westerly Amazon River discharge, coastal junctions during times of marine regressions 
Table 3. Taxa list, specimen and sequence data analyzed in the present study $(n=44)$. Institutional acronyms follow Fricke and Eschmeyer (2013).

\begin{tabular}{|c|c|c|c|c|}
\hline Species & $\begin{array}{l}\text { Catalog } \\
\text { Number }\end{array}$ & $\begin{array}{c}\text { Field } \\
\text { Number }\end{array}$ & $\begin{array}{l}\text { GenBank No } \\
\text { F-RTN4 }\end{array}$ & Ref. \\
\hline Corydoras oiapoquensis & $\begin{array}{c}\text { MHNG } \\
2682.023\end{array}$ & GF06-186 & GU210997 & Alexandrou et al. (2011) \\
\hline Hemipsilichthys gobio & LBP 2368 & 15363 & EU817547 & Chiachio et al. (2008) \\
\hline Harttia guianensis & $\begin{array}{c}\text { MHNG } \\
2643.016 \\
\end{array}$ & GF00-351 & FJ013232 & Chiachio et al. (2008) \\
\hline Hypostomus sp. & $\begin{array}{c}\text { MHNG } \\
2721.062 \\
\end{array}$ & PE08-198 & JN855790 & Covain and Fisch-Muller (2012) \\
\hline $\begin{array}{l}\text { Hypostomus boulengeri (Eigenmann \& } \\
\text { Kennedy, 1903) }\end{array}$ & $\begin{array}{l}\text { MHNG } \\
2519.23\end{array}$ & ASU7 & EU817560 & Chiachio et al. (2008) \\
\hline H. gymnorhynchus (Norman, 1926) & $\begin{array}{c}\text { MHNG } \\
2621.098 \\
\end{array}$ & SU01-160 & JN855789 & Covain and Fisch-Muller (2012) \\
\hline Ancistrus cirrhosis (Valenciennes, 1836) & $\begin{array}{l}\text { MHNG } \\
2645.037\end{array}$ & MUS 202 & HM623638 & Rodriguez et al. (2011) \\
\hline Dekeyseria picta (Kner, 1854) & $\begin{array}{c}\text { MHNG } \\
2588.046\end{array}$ & MUS 162 & JN855755 & Covain and Fisch-Muller (2012) \\
\hline D. scaphirhyncha (Kner, 1854) & $\begin{array}{l}\text { AUM } \\
43874 \\
\end{array}$ & V5528 & JN855756 & Covain and Fisch-Muller (2012) \\
\hline Hemiancistrus medians (Kner, 1854) & $\begin{array}{c}\text { MHNG } \\
2664.078 \\
\end{array}$ & GF00-084 & JF747011 & Fisch-Muller et al. (2012) \\
\hline Guyanancistrus brevispinis & $\begin{array}{l}\text { MHNG } \\
2725.099\end{array}$ & GF00-103 & JN855772 & Covain and Fisch-Muller (2012) \\
\hline G. brevispinis & $\begin{array}{l}\text { MHNG } \\
2621.073\end{array}$ & SU01-121 & JN855773 & Covain and Fisch-Muller (2012) \\
\hline G. longispinis & $\begin{array}{c}\text { MHNG } \\
2725.100 \\
\end{array}$ & GF99-204 & JN855757 & Covain and Fisch-Muller (2012) \\
\hline G. niger & $\begin{array}{l}\text { MHNG } \\
2722.089\end{array}$ & GF99-185 & JN855759 & Covain and Fisch-Muller (2012) \\
\hline Guyanancistrus sp. & $\begin{array}{c}\text { MHNG } \\
2679.099\end{array}$ & MUS 300 & JN855774 & Covain and Fisch-Muller (2012) \\
\hline $\begin{array}{l}\text { Hopliancistrus tricornis Isbrücker \& } \\
\text { Nijssen, } 1989\end{array}$ & $\begin{array}{l}\text { MHNG } \\
2588.051\end{array}$ & MUS 146 & JN855765 & Covain and Fisch-Muller (2012) \\
\hline Lasiancistrus aff. caucanus & $\begin{array}{c}\text { MHNG } \\
2586.043\end{array}$ & MUS 118 & JN855786 & Covain and Fisch-Muller (2012) \\
\hline L. heteracanthus (Günther, 1869) & $\begin{array}{l}\text { MHNG } \\
2613.037\end{array}$ & CA 013 & JN855787 & Covain and Fisch-Muller (2012) \\
\hline $\begin{array}{l}\text { L. planiceps (Meek \& Hildebrand, } \\
\text { 1913) }\end{array}$ & $\begin{array}{l}\text { STRI- } \\
01805\end{array}$ & Stri 3526 & JN855785 & Covain and Fisch-Muller (2012) \\
\hline L. saetiger Armbruster 2005 & $\begin{array}{l}\text { MHNG } \\
2602.016\end{array}$ & BR98-148 & JN855754 & Covain and Fisch-Muller (2012) \\
\hline L. schomburgkii (Günther, 1869) & $\begin{array}{l}\text { MHNG } \\
2651.009\end{array}$ & PE08-719 & JN855782 & Covain and Fisch-Muller (2012) \\
\hline L. schomburgkii & $\begin{array}{l}\text { MHNG } \\
2651.068\end{array}$ & GY04-308 & JN855783 & Covain and Fisch-Muller (2012) \\
\hline$L$, schomburgkii & $\begin{array}{c}\text { MHNG } \\
2710.055\end{array}$ & PE08-277 & JN855784 & Covain and Fisch-Muller (2012) \\
\hline L. tentaculatus Armbruster, 2005 & $\begin{array}{c}\text { MhnG } \\
\text { uncat. }\end{array}$ & MUS 573 & JN855788 & Covain and Fisch-Muller (2012) \\
\hline Lithoxus lithoides Eigenmann, 1912 & $\begin{array}{l}\text { MHNG } \\
2651.087\end{array}$ & GY04-136 & JN855777 & Covain and Fisch-Muller (2012) \\
\hline L, pallidimaculatus Boeseman, 1982 & $\begin{array}{l}\text { MHNG } \\
2621.066\end{array}$ & SU01-096 & JN855778 & Covain and Fisch-Muller (2012) \\
\hline L. planquettei Boeseman, 1982 & $\begin{array}{c}\text { MHNG } \\
2722.060 \\
\end{array}$ & GF03-055 & JN855779 & Covain and Fisch-Muller (2012) \\
\hline
\end{tabular}




\begin{tabular}{|c|c|c|c|c|}
\hline Species & $\begin{array}{l}\text { Catalog } \\
\text { Number }\end{array}$ & $\begin{array}{c}\text { Field } \\
\text { Number }\end{array}$ & $\begin{array}{l}\text { GenBank No } \\
\text { F-RTN4 }\end{array}$ & Ref. \\
\hline Lithoxancistrus orinoco & $\begin{array}{l}\text { AUM } \\
43725\end{array}$ & V5246 & JN855766 & Covain and Fisch-Muller (2012) \\
\hline L. orinoco & $\begin{array}{l}\text { AUM } \\
42179 \\
\end{array}$ & P4527 & JN855767 & Covain and Fisch-Muller (2012) \\
\hline Pseudancistrus barbatus & $\begin{array}{l}\text { MHNG } \\
2653.059\end{array}$ & GF00-074 & JN855761 & Covain and Fisch-Muller (2012) \\
\hline P. corantijniensis & $\begin{array}{l}\text { MHNG } \\
2672.092 \\
\end{array}$ & SU05-296 & JN855781 & Covain and Fisch-Muller (2012) \\
\hline P. depressus & $\begin{array}{l}\text { MHNG } \\
2674.026\end{array}$ & SU05-020 & JN855780 & Covain and Fisch-Muller (2012) \\
\hline P. genisetiger & $\begin{array}{l}\text { MHNG } \\
2593.061\end{array}$ & MUS 173 & JN855764 & Covain and Fisch-Muller (2012) \\
\hline P. nigrescens & $\begin{array}{l}\text { MHNG } \\
2651.069\end{array}$ & GY04-313 & JN855770 & Covain and Fisch-Muller (2012) \\
\hline P. nigrescens & $\begin{array}{l}\text { MHNG } \\
2650.087 \\
\end{array}$ & GY04-260 & JN855771 & Covain and Fisch-Muller (2012) \\
\hline P. pectegenitor & $\begin{array}{l}\text { AUM } \\
42202\end{array}$ & V5363 & JN855769 & Covain and Fisch-Muller (2012) \\
\hline P. pectegenitor & $\begin{array}{l}\text { ANSP } \\
182801\end{array}$ & V5433 & JN855768 & Covain and Fisch-Muller (2012) \\
\hline P. sidereus & $\begin{array}{l}\text { AUM } \\
43443 \\
\end{array}$ & P4871 & JN855775 & Covain and Fisch-Muller (2012) \\
\hline P. sidereus & $\begin{array}{l}\text { AUM } \\
42180\end{array}$ & P4537 & JN855776 & Covain and Fisch-Muller (2012) \\
\hline P. zawadzkii & $\begin{array}{l}\text { LBP } \\
15045\end{array}$ & 61628 & KJ028080 & Present study \\
\hline Pseudancistrus sp. L17 & $\begin{array}{c}\text { MHNG } \\
2586.046\end{array}$ & MuS 132 & JN855763 & Covain and Fisch-Muller (2012) \\
\hline Pseudolithoxus cf. kelsorum & $\begin{array}{l}\text { MHNG } \\
2679.043\end{array}$ & MUS 260 & JN855762 & Covain and Fisch-Muller (2012) \\
\hline $\begin{array}{l}\text { P. dumus (Armbruster \& Provenzano, } \\
\text { 2000) }\end{array}$ & $\begin{array}{l}\text { MHNG } \\
2708.080\end{array}$ & MUS 288 & JN855760 & Covain and Fisch-Muller (2012) \\
\hline $\begin{array}{l}\text { P. tigris (Armbruster \& Provenzano, } \\
\text { 2000) }\end{array}$ & $\begin{array}{l}\text { AUM } \\
42215\end{array}$ & V5292 & JN855758 & Covain and Fisch-Muller (2012) \\
\hline
\end{tabular}

and expanded coastal plains, and stream captures (Eigenmann 1912; Boeseman 1968; Cardoso and Montoya-Burgos 2009; Lujan and Armbruster 2011).

Additionally, the mainstream of Amazon River can act as a permeable barrier for endemic taxa on the respective Guiana and Brazilian shields. Several genera known to tolerate more lowland conditions (e.g. Ancistrus Kner, 1854, Lasiancistrus, and Hypostomus Lacepéde, 1803) may be able to cross the Amazon basin, but such dispersal is unlikely among most species of Ancistrini (Lujan and Armbruster 2011). Also historically, epochs of cooler climate, as during glacial periods, could produce reduced precipitation, marine regressions, expansion of the coastal plain, and deepening of river channels. During such arid periods, rapids would have been more widespread, and deep-channel habitats that may currently work as barriers to fish dispersal would have been reduced (Schubert et al. 1986; Latrubesse and Franzinelli 2005; Lujan and Armbruster 2011). Drier climate will hardly change the Amazon river in a rapid, but can reduce its water flow allowing fish dispersal. Among Neotropical fishes Psectro- 


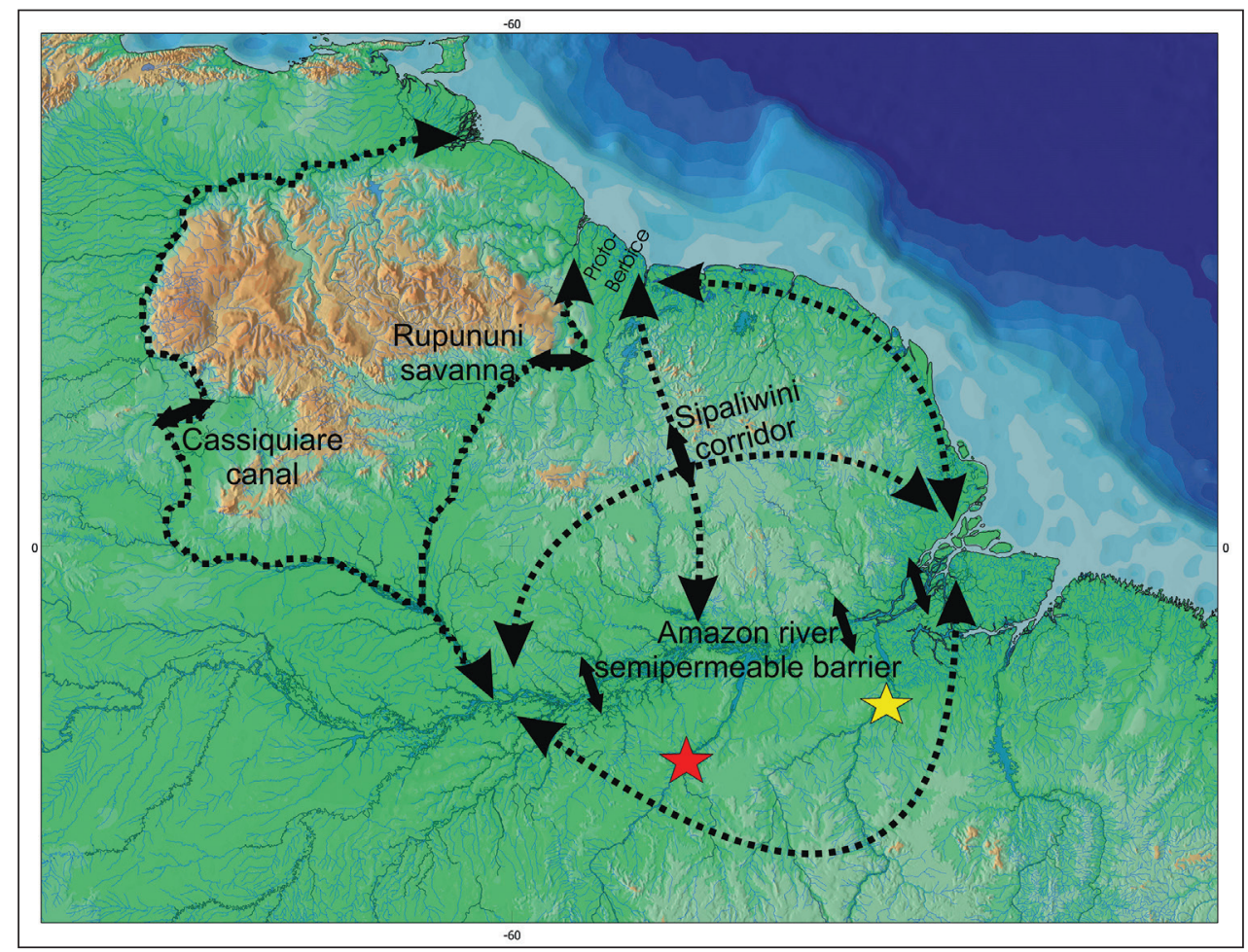

Figure 7. Hypothesized dispersal routs between basins of the Guiana Shield and Amazon Shield of ancestror of the Pseudancistrus barbatus group (based on Lujan and Armbruster 2011). Our second hypothesis of the $P$. barbatus group extent-species distribution is based on the assumption of a widespread ancestral through all Guyana Shield rivers and dispersal events enable the ancestor of Pseudancistrus zawadzkii (red star) and Pseudancistrus sp. L17 (yellow star) to colonize the Amazon Brazilian Shield rivers in Tapajós and Xingu rivers.

gaster essequibensis Günther, 1864 (Characiformes: Curimatidae; see Vari (1987)), Parotocinclus aripuanensis Garavello, 1988, and P. britskii Boeseman, 1974 (Loricariidae: Hypoptopomatinae) are species known to support dispersal via the northern Brazilian Shield.

Also, the dispersal routes around adjacent drainages of southern and northern Guyana Shield and northern parts of the Brazilian Shield could allow the dispersal of the ancestral form of P. zawadzkii and Pseudancistrus sp. L17, as well as others ancestral species of the P. barbatus group and even species of Ancistrini (Lujan and Armbruster 2011). The movement of fish species around adjacent drainages could be explained by two hydrographic reconfiguration process: headwater capture events (geomorphological phenomenon) and marine regressions (sea level oscillation). Changes in the earth's surface involving changes in the courses of rivers, as stream captures, portions of tributaries of a river in a watershed could be "captured" by adjacent basins resulting in isolated populations and at the same time letting species to move, or disperse, between 
adjacent drainages (Almeida and Carneiro 1998; Bishop 1995; Wilkinson et al. 2006, 2010; Roxo et al. 2012). Montoya-Burgos (2003) hypothesized that dispersal (followed by allopatric population divergence) among Amazon and North-eastern coastal rivers probably occurred by temporary connections between adjacent rivers during periods of lower sea level about 6-5 Ma (see fig. 5 in Montoya-Burgos 2003). Cardoso and Montoya-Burgos (2009) suggested the same process to explain dispersal of $P$. brevispinis along coastal rivers of the Guyana. Therefore, temporary lowland connections and headwater capture events, together with the previously related hypothesis of colonization routes, likely explain the widespread distribution of the $P$. barbatus group extant species on Guyana and Brazilian Shields, as well as how the ancestral lineages of $P$. zawadzkii and Pseudancistrus sp. L17 reached the drainages of the northern Brazilian Shield, in Tapajós and Xingu rivers.

\section{Comparative material}

Pseudancistrus barbatus (Valencienes, 1840): ANSP 177366, 2, 76.5-103.7 mm SL, Burro Burro river, Water Dog Falls, Essequibo river basin, Guyana. ANSP 189119, 3, 75.1-151.5 mm SL, Lawa river, Sipalawini, Suriname. Pseudancistrus brevispinis (Heitmans, Nijssen \& Isbrücker, 1983): ANSP 189128, 3, 56.8-125.7 mm SL, Marowini river, Sipalawini, Suriname. Pseudancistrus nigrescens Eigenmann, 1912: ANSP 177379, 5, 96.4-133.5 mm SL, Burro Burro river, Water Dog Falls, Essequibo river basin, Guyana. Pseudancistrus orinoco (Isbrücker, Nijssen \& Cala, 1988): ANSP 160600, 6, 68.0-78.5 mm SL, Orinoco river, Venezuela. Pseudancistrus pectegenitor Lujan, Armbruster \& Sabaj, 2007: ANSP 190755, 1, 206,2 mm SL, Ventuari river, Orinoco river basin, Venezuela. Pseudancistrus sidereus Armbruster, 2004b: ANSP 185321, 4, 148.6-154.1 mm SL, Casiquiari river, Venezuela. Pseudancistrus sp. L17: LBP 16551, 2, 75.3-101.0 mm SL; rio Xingu, Altamira, Pará State, Amazon river basin, Brazil. ANSP 193074, 3, 51.7-188.7 mm SL, Xingu river, Altamira, Pará State, Amazon river basin, Brazil. Pseudancistrus sp. ANSP 191153, 6, 49.2-75.7 mm SL, Ventuari river, Orinoco river basin, Venezuela.

\section{Acknowledgements}

We are grateful to M.H. Sabaj Pérez (Academy of Natural Sciences of Philadelphia) and J.S. Albert (University of Louisiana at Lafayette) for loans of specimens and curatorial assistance; to CEPTA's team (Centro de Pesquisa Treinamento em Aquicultura - formerly Centro Nacional de Pesquisa e Conservação de Peixes Continentais) for help collecting specimens; B. Waltz and again to M.H. Sabaj Pérez for reading the manuscript and providing valuable suggestions. Fishes collected in accordance with Brazilian laws, under a permanent scientific collecting license issued to Dr. Claudio Oliveira by IcmBio/CEPTA. Research supported by Brazilian agencies FAPESP (Fundação 
de Amparo à Pesquisa do Estado de Sáo Paulo, proc. 2010/01610-9 to FFR, proc. 2012/01622-2 to GSCS and proc. 2011/00269-4 to RB), MCT/CNPq (Conselho Nacional de Desenvolvimento Científico e Tecnológico) and CAPES (Coordenação de Aperfeiçoamento de Pessoal de Nível Superior). Comparative material from rio Xingu made available by iXingu Project funded by the U.S. National Science Foundation (DEB-1257813).

\section{References}

Almeida FFM, Carneiro CDR (1998) Origem e evolução da Serra do Mar. Revista Brasileira de Geociências 28: 135-150.

Armbruster JW, Provenzano F (2000) Four new species of the Suckermouth armored catfish genus Lasiancistrus (Loricariidae: Ancistrinae). Ichthyological Exploration Freshwaters 11: 241-254.

Armbruster JW (2003) Peckoltia sabaji, a new species from the Guyana Shield (Siluriformes, Loricariidae). Zootaxa 344: 1-12.

Armbruster JW (2004a) Phylogenetic relationships of the sucker-mouth armored catfishes (Loricariidae) with particular emphasis on the Hypostominae and the Ancistrinae. Zoological Journal of the Linnean Society 141: 1-80. doi: 10.1111/j.1096-3642.2004.00109.x

Armbruster JW (2004b) Pseudancistrus sidereus, a new species from southern Venezuela (Siluriformes: Loricariidae) with a redescription of Pseudancistrus. Zootaxa 628: 1-15.

Armbruster JW (2005) The loricariid catfish genus Lasiancistrus (Siluriformes) with descriptions of two new species. Neotropical Ichthyology 3(4): 549-569. doi: 10.1590/S167962252005000400013

Armbruster JW (2008) The genus Peckoltia with the description of two new species and a reanalysis of the phylogeny of the genera of Hypostominae (Siluriformes: Loricariidae). Zootaxa 1822: 1-76.

Bishop P (1995) Drainage rearrangement by river capture, beheading and diversion. Progress in Physical Geography 19: 449-473. doi: 10.1177/030913339501900402

Boeseman M (1968) The genus Hypostomus Lacépède, 1803, and its Surinam representatives (Siluriformes, Loricariidae). Zoologische Verhandelingen 99: 1-89.

Boeseman M (1974) On two Surinam species of Hypoptopomatinae, both new to science (Loricariidae, Siluriformes, Ostariophysi) Proc. Kon. Nederl. Acad. Wetensh 77(3): 275-271.

Boeseman M (1982) The South American mailed catfish genus Lithoxus Eigenmann, 1910, with the description of three new species from Surinam and French Guyana and records of related species (Siluriformes, Loricariidae). Proc. Kon. Nederl. Acad. Wetensh. (Ser. C, Biol. Med. Sci), 85(1): 41-58, pls. 1-5.

Buckup PA (1993) Review of the characidiin fishes (Teleostei: Characiformes), with descriptions of four new genera and ten new species. Ichthyological Exploration of Freshwaters 4:97-154.

Cardoso YP, Montoya-Burgos JI (2009) Unexpected diversity in the catfish Pseudancistrus brevispinis reveals dispersal routes in a Neotropical center of endemism: The Guyanas Region. Molecular Ecology 18: 947-964. doi: 10.1111/j.1365-294X.2008.04068.x 
Chambrier S, Montoya-Burgos JI (2008) Pseudancistrus corantijniensis, a new species from the Guyana Shield (Siluriformes: Loricariidae) with a molecular and morphological description of the Pseudancistrus barbatus group. Zootaxa 1918: 45-58.

Chernoff B, Machado-Allison A, Saul WG (1991) Morphology, variation and biogeography of Leporinus brunneus (Pisces: Characiformes: Anostomidae). Ichthyological Exploration of Freshwaters 1: 295-306.

Chiachio MC, Oliveira C, Montoya-Burgos JI (2008) Molecular systematic and historical biogeography of the armored Neotropical catfishes Hypoptopomatinae and Neoplecostominae (Siluriformes: Loricariidae). Molecular Phylogenetics and Evolution 49: 606-617. doi: 10.1016/j.ympev.2008.08.013

Covain R, Fisch-Muller S (2012) Molecular evidence for the paraphyly of Pseudancistrus sensu lato (Siluriformes, Loricariidae), with revalidation of several genera. Cybium 36(1): 229-246.

Cuvier G, Valenciennes A (1840) Histoire naturelle des poissons. Tome quinzième. Suite du livre dix-septième. Siluroïdes 15: 421-455.

De Chambrier S, Montoya-Burgos JI (2008) Pseudancistrus corantijniensis, a new species from the Guyana Shield (Siluriformes: Loricariidae) with a molecular and morphological description of the Pseudancistrus barbatus group. Zootaxa 1918: 45-58.

De Souza LS, Armbruster JW, Werneke DC (2012) The influence of the Rupununi portal on distribution of freshwater fish in the Rupununi district, Guyana. Cybium 36(1): 31-43.

Eigenmann CH (1910) Catalogue of the fresh-water fishes of tropical and south temperate America. In: Reports of the Princeton University expeditions to Patagonia 1896-1899. Zoology 3: 375-511

Eigenmann CH (1912) The freshwater fishes of British Guiana, including a study of the ecological grouping of species and the relation of the fauna of the plateau to that of the lowlands. Memoirs of the Carnegie Museum 5: $578+51$ pls.

Eigenmann CH, Kennedy (1903) On a collection of fishes from Paraguay, with a synopsis of the American genera of cichlids. Proceedings of Academy of Natural Sciences of Philadelphia 55: 497-537.

Eschmeyer WN, Fong JD (2013) Catalog of fishes. Online version, updated 07 january 2013. http://research.calacademy.org/research/ichthyology/catalog/SpeciesByFamily.asp

Fowler HW (1941) A collection of fresh-water fishes obtained in eastern Brazil by Dr. Rodolpho von Ihering. Proceedings of the Academy of Natural Sciences of Philadelphia 93: 123-199.

Fricke R, Eschmeyer WN (2013) Catalog of fishes. Online version, updated 07 January 2013. http://research.calacademy.org/research/ichthyology/catalog/collections.asp

Garavello JC (1988) Three new species of Parotocinclus Eigenmann \& Eigenmann, 1889 (Ostariophysi, Loricariidae) Arquivos de Zoologia (São Paulo) 28(4): 1-37. doi: 10.11606/ issn.2176-7793.v28i4p1-37

Gaston KJ (1998) Species-rangesize distribuitions: Products of speciations, extinctions and transformation. Philosophical Transactions of the Royal Society of London, Series B-Biological Sciences 353: 219-230. doi: 10.1098/rstb.1998.0204 
Günther A (1868) Diagnoses of some new freshwater fishes from Surinam and Brazil, in the collection of the British Museum. Annals and Magazine of Natural History 1(6): 475-481. doi: 10.1080/00222936808695733

Hall TA (1999) BioEdit: a user-friendly biological sequence aligment editor and analysis program for Windows 95/92/NT. Nucleic Acid Symposium Series 41: 95-98.

Heitmans WRB, Nijssen H, Isbrücker IJH (1983) The mailed catfish genus Lasiancistrus Regan, 1904, from French Guiana and Surinam, with descriptions of two new species (Pisces, Siluriformes, Loricariidae). Bijdragen tot de Dierkunde 53(1): 33-48.

Hubbell SP (2001) The Unified Neutral Theory of Biodiversity and Biogeography. University Press, Princenton, NJ.

Isbrücker IJH, Nijssen H, Cala P (1988) Lithoxancistrus orinoco, nouveau genre et espèce de poisson-chat cuirassé du Rio Orinoco en Colombie (Pisces, Siluriformes, Loricariidae). Revue française d'Aquariologie Herpétologie 15: 13-16.

Isbrücker IJH, Seidel I, Michels JP, Schraml E, Werner A (2001) Diagnose vierzehn neuer Gattungen der Familie Loricariidae Rafinesque, 1815 (Teleostei, Ostariophysi). DatzSonderheft "Harnischwelse 2": 17-24.

Jobb G, von Haeseler A, Strimmer K (2004) TREEFINDER: a powerful graphical analysis environment for molecular phylogenetics. BMC Evolutionary Biology 4: 4-18. doi: $10.1186 / 1471-2148-4-18$

Latrubesse EM, Franzinelli E (2005) The late Quaternary evolution of the Negro River, Amazon, Brazil: Implications for island and floodplain formation in large anabranching tropical systems. Geomorphology 70: 372-397. doi: 10.1016/j.geomorph.2005.02.014

Lacepéde BGE (1803) Histoire naturelle des poissons. Vol. 5. Plassan, Paris. 1xviii+803 p.+index, pls 1-21

Lujan NK, Armbruster JW (2011) The Guiana Shield. In: Albert JS, Reis RE (Eds) Historical Biogeography of Neotropical Freshwater Fishes. University of California Press, Berkeley, 211-224. doi: 10.1525/california/9780520268685.003.0013

Lujan NK, Armbruster JW, Sabaj MH (2007) Two new species of Pseudancistrus from southern Venezuela (Siluriformes: Loricariidae). Ichthyological Exploration of Freshwaters 18(2): 163-174.

Lütken CF (1874) Ichthyographiske bidrag. I. Nogle nye eller mindre fuldstaendigt kjendte Pandsermaller, isaer fra det nordlige Sydamerica. Vidensk. Medd. Dansk Naturh. Foren. Kjob. (for 1873), No. 13-14: 202-220, pl.4.

Lovejoy NR, Araújo ML (2000) Molecular systematics, biogeography and population structure of Neotropical freshwater needle-fishes of the genus Potamorrhaphis. Molecular Ecology 9: 259-268. doi: 10.1046/j.1365-294x.2000.00845.x

Kner R (1854) Die Hypostomiden. Zweite Hauptgruppe der Familie der Panzerfische. (Loricata vel Goniodontes). Denkschriften der Akademie der Wissenschaften in Wien, 7: 251-286, pls. 1-5.

Meek SE, Hildebrand (1913) New species of fishes from Panama. Field Mus. Hist. Publ. Zool. Ser 10(8): 77-91. 
Montoya-Burgos JI (2003) Historical biogeography of the catfish genus Hypostomus (Siluriformes: Loricariidae), with implications on the diversification of Neotropical ichthyofauna. Molecular Ecology 12: 1855-1867. doi: 10.1046/j.1365-294X.2003.01857.x

Moyer GR, Winemiller KO, McPhee MV, Turner TF (2005) Historical demography, selection, and coalescence of mitochondrial and nuclear genes in Prochilodus species of northern South America. Evolution 59: 599-610.

Nijssen H (1972) Records of the catfish genus Corydoras from Brazil and French Guiana with descriptions of eight new species (Pisces, Siluriformes, Callichthyidae). Netherlands J. Zool. 21(4): 412-433, pls. 1-3.

Norman JR (1926) Descriptions of nine new freshwater fishes from French Guiana and Brazil. Annals and Magazine of natural History. (Ser. 9), 18 (no. 103): 91-97.

Roxo FF, Zawadzki CH, Alexandrou MA, Costa Silva GJ, Chiachio MC, Foresti F, Oliveira C (2012) Evolutionary and biogeographic history of the subfamily Neoplecostominae (Siluriformes: Loricariidae). Ecology and Evolution 2: 2438-2449. doi: 10.1002/ece3.368

Rapp Py-Daniel LH, Oliveira EC (2001) seven new species of Harttia from the AmazonianGuyana region (Siluriformes: Loricariidae). Ichthyological. Exploration of Fresh waters 12(1): 79-96.

Regan CT (1904) A monongraph of the fishes of the family Loricariidae. Transactions of the Zoological Society of London 17 (3, no. 1): 191-350, pls. 9-21.

Schaefer SA, Provenzano F (1993) The Guyana shield Parotocinclus: Systematics, biogeography, and description of a new Venezuelan species (Siluroidei: Loricariidae). Ichthyological Exploration of Freshwaters 4: 39-56.

Schubert C, Briceño HO, Fritz P (1986) Paleoenvironmental aspects of the Caroni-Paragua River Basin (Southeastern Venezuela). Interciencia 11: 278-289.

Seidel I (2008) Back to Nature Guide to L-Catfishes. Fohrman Aquaristik AB, Sweden, 208 pp.

Shimodaira H (2002) An approximately unbiased test of phylogenetic tree selection. Systematic Biology 51: 492-508. doi: 10.1080/10635150290069913

Shimodaira H, Hasegawa M (1999) Multiple comparisons of log-likelihoods with applications to phylogenetic inference. Molecular Biology and Evolution 16: 1114-1116. doi: 10.1093/ oxfordjournals.molbev.a026201

Stamatakis A, Hoover P, Rougemont J (2008) A rapid bootstrap alogarithm for the RAxML web Servers. Systematic Biology 75: 758-771. doi: 10.1080/10635150802429642

Strimmer K, Rambaut A (2002) Inferring confidence sets of possibly misspecified gene trees. Proceedings of the Royal Society B 269: 137-142. doi: 10.1098/rspb.2001.1862

Turner TF, McPhee MV, Campbell P, Winemiller KO (2004) Phylogeography and intraspecific genetic variation of prochilodontid fishes endemic to rivers of northern South America. Journal of Fish Biology 64: 186-201. doi: 10.1111/j.1095-8649.2004.00299.x

Wilkinson MJ, Marshall LG, Lundberg JG (2006) River behavior on megafans and potential influences on diversification and distribution of aquatic organisms. Journal South American Earth Sciences 21: 151-172. doi: 10.1016/j.jsames.2005.08.002

Wilkinson MJ, Marshall LG, Lundberg JG, Kreslavsky MH (2010) Megafan environments in northern South America and their impact on Amazon Neogene aquatic ecosystems. In: 
Horn C, Wesselingh EP (Eds) Amazonia, Landscape and Species Evolution: A Look into the Past. Blackwell Publishing, 165-185.

Willink PW, Mol JH, Chernoff B (2010) A new species of suckermouth armored catfish, Pseudancistrus kwinti (Siluriformes:Loricariidae) from the Coppename River drainage, Central Suriname Nature Reserve, Suriname. Zootaxa 2332: 40-48.

Willis SC, Nunes MS, Montana CG, Farias IP, Lovejoy NR (2007) Systematics, biogeography, and evolution of the Neotropical peacock basses Cichla (Perciformes: Cichlidae). Molecular Phylogenetics and Evolution 44: 291-307. doi: 10.1016/j.ympev.2006.12.014

Winemiller KO, López-Fernández H, Taphorn DC, Nico LG, Barbarino-Duque A (2008) Fish assemblages of the Casiquiare River, a corridor and zoogeographical filter for dispersal between the Orinoco and Amazon basins. Journal of Biogeography 35: 1551-1563. doi: 10.1111/j.1365-2699.2008.01917.x

Winemiller KO, Willis SC (2011) The Guiana Shield. In: Albert JS, Reis RE (Eds) Historical Biogeography of Neotropical Freshwater Fishes. University of California Press, Berkeley, 225-242.

Valenciennes A (1836) Poissons [pl. 7]. In: A. d' Orbigny. Voyage dans L'Amérique Méridionale (le Brésil, la République Argentine, la Patagonie, la République du Chili, la République de Bolivie.

Xia X, Xie X (2001) Dambe: Data analysis in molecular biology and evolution. Journal of Heredity 92: 371-373.

Xia X, Xia Z, Salemi M, Chen L, Wang Y (2003) An index of substituition saturation and its application. Molecular Phylogenetic and Evolution 26: 1-17. doi: 10.1016/S10557903(02)00326-3

Xia X, Lemey P (2009) Assessing substituition saturation with DAMBE. In: Lemey P, Salemi M, Vandamme A-M (Eds) The phylogenetic Handbook: A pratical approach to DNA and Protein Phylogeny. Second edition. Cambridge University Press, Cambridge, 615-630. doi: 10.1017/CBO9780511819049.022 